IRSH 49 (2004), pp. 7I-I02 DOI: I0.1017/S002085900300I 378

(C) 2004 Internationaal Instituut voor Sociale Geschiedenis

\title{
Leading the White-Collar Union: Clive Jenkins, the Management of Trade-Union Officers, and the Politics of the British Labour Movement, c.1968-1979*
}

\author{
J OSEPH MELLING
}

Summary: The growth of white-collar unionism and its impact on British trade unions in the postwar period has received little attention from social historians. Radical critics have noted the failure of Clive Jenkins to provide a clear lead in defending workers' conditions, while mainstream, institutionalist commentators more often stress the diversity of specific interests served by such unions. Recent research has called into question earlier models of union governance, though there remain few studies of the history of officer relations within trade unions. This article examines the leadership of ASTMS in the decade after its formation. It is argued that the strategies pursued by Jenkins, including the recruitment, training, and deployment of fieldworkers, were guided by accumulated knowledge and culture (as well as brilliant opportunism) rather than by the structure of the union or the composition of the membership. In offering educated officers a career structure, ASTMS increased its capacity for expertise and effective communication without descending into the political sectarianism of the postwar years. The charismatic, capricious style adopted by Jenkins, as well as the difficulties of absorbing a diverse membership in this period of rapid growth, contributed to the tensions which culminated in a series of struggles between the union and its bargainers during the I 970 s.

\section{INTRODUCTION: MODELS OF ORGANIZATION}

In a television programme broadcast in I975, the veteran Labour politician, Ian Mikardo, paid tribute to the General Secretary of the largest white-collar union in the United Kingdom. According to Mikardo,

\footnotetext{
* Acknowledgements: The research on which these articles are based was funded by the Economic and Social Research Council and by the Arts and Humanities Research Board. I am indebted to present and former members of the ASTMS and MSF-Amicus who contributed to my research, including those identified as interviewees. In particular, the late Clive Jenkins, the late Will Rowe, Baroness Turner, and Gary Morton generously shared original documents with me as well as consenting, as did many others, to be interviewed. The staff of the Modern Record Centre, Warwick University, and the BBC Written Archives Centre, Caversham, provided patient assistance. Critical comments were provided by Alan Booth, Mark Bufton, Bob Carter, John Fisher, Don Groves, David Lyddon, Paul Smith, Andrew Thorpe and the editors of IRSH.
} 
Clive Jenkins was the best industrial manager he had ever met, combining strategic vision with "sheer organizational, administrative ability and drive". The result was that the Association of Scientific, Technical and Managerial Staffs (ASTMS) had become the fastest-growing trade union of the post-I945 years. ${ }^{1}$ Jenkins's undoubted talent for exploiting the mass media to project his personality and political preferences, while marketing white-collar unionism to a sceptical audience of salaried employees, was an important element in his success. The ASTMS leader seized every opportunity to associate trade unionism with innovation and modernity, suggesting that Britain's Conservative Party were wedded to an outdated style of class conflict while socialists were engineering progressive change in contemporary society. ${ }^{2}$ The impact of mass communications on the appeal and style of modern trade unionism has attracted limited attention from social and cultural historians, though leading Labour politicians such as Harold Wilson clearly appreciated the impact of attaching the rhetoric of modernization to a party which was struggling to renew its appeal to the British electorate in the I960s. As a prominent member of ASTMS and confidante of Jenkins, Wilson also appreciated the efforts made by whitecollar unions to recruit middle-income staff to the trade-union movement. ${ }^{3}$

Debates on the history of white-collar unionism have frequently been concerned with broader questions of the class identity of salaried employees as well as the influence of institutional structures on the accountability of union leaders to different sections of the membership. Such discussions have often turned on the interpretation of the unionization of nonmanual employees as the expression of class identity, either as a consequence of the degradation of salaried employment and the terms on which salaried labour was sold, or as the collective movement of a new working class based on postindustrial technologies and markets. ${ }^{4}$ The classical study of white-collar unionism in the United Kingdom, published by George Bain in 1970, rejected Weberian and Marxist explanations of trade-union recruitment among the middle classes. Bain's criticisms of

I. Transcript of British Broadcasting Corporation (BBC) programme, Face Your Image, transmitted 2 I February 1975, p. 5. Copy at BBC Written Archives Centre, Caversham, Reading.

2. Face Your Image, p. Io. Jenkins told David Dimbleby, "I would have thought these other class delineations and boundaries were incredibly old-fashioned. The problem with our country is that it is not modern enough."

3. Interview with Richard Clements, 25 September 2002; interview with Greta Karpin, 22 August 2002. Harold Wilson was a long-standing ASSET member.

4. Richard Hyman, "White-Collar Workers and Theories of Class", in Richard Hyman and Robert Price (eds), The New Working Class? White-Collar Workers and Their Organizations: A Reader (London, 1983), pp. 3-4I; Theo Nichols, "Introduction" to Peter Armstrong, Bob Carter, Chris Smith and Theo Nichols, White Collar Workers, Trade Unions and Class (London, 1986) pp. I-I 4 and passim, for an evaluation of the earlier literature. 
sociological studies linking the growth of salaried unionism to the erosion of middle-class status or the emergence of new social forces were developed in this and subsequent studies which stress the importance of specific market, institutional, and political conditions which favoured the growth of the new unionism.5 Marxist scholars were in the forefront of those criticizing Bain's emphasis on such factors as the benign impact of government regulation in union expansion among white-collar employees. Research by Peter Armstrong, Bob Carter, and others demonstrated the impact of workplace change, industrial conflict, and resistance to statutory wage controls in the mobilization of support for unions such as ASTMS in the I970s and I980s. ${ }^{6}$ Radical assessments of the periodic divergence between officials and the rank-and-file members of trade unions, such as Carter's detailed investigation of ASTMS and the career of Clive Jenkins, continue to be debated in the literature as scholars differ in their interpretation of the workplace action and institutional traditions among the workforce. ${ }^{7}$ Much criticized in recent years, the radical analysis of union officials provides a valuable understanding of the ways in which the employees of unions can promote their career interests and pursue recruitment or mergers as a means of furthering personal projects.

These exchanges on the class context and orientation of salaried staff have contributed to a reinterpretation of trade-union governance. An important feature of the literature on white-collar unionism which has developed in labour history, as well as in the analysis of contemporary industrial relations, has been the role of the trade-union officer in the governance of the union. In an important study of trade-union growth, governance and leadership, Undy et al. emphasize the binary nature of decision-making in such unions as ASTMS, where bargaining was decentralized but policy-making was largely the province of a National Executive Council (NEC) dominated by Jenkins as General Secretary, with intermittent challenges to this highly centralized control by the

5. G.S. Bain, The Growth of White Collar Unionism (Oxford, 1970), pp. I80-18 I and passim. 6. Peter Armstrong, "Class and Control at the Point of Production: Foremen", in Armstrong, et al., White Collar Workers, pp. 19-29 and passim; Bob Carter, Capitalism, Class Conflict and the New Middle Class (London, 1985), pp. 163-167, 200-202, 234-235. Also W.G. Runciman, Relative Deprivation and Social Justice (Harmondsworth, I972), pp. I84-200 and passim for social-survey evidence.

7. Bob Carter, "Trade Unionism and the New Middle Class: The Case of ASTMS", in Armstrong, et al., White Collar Workers, pp. I4I-I 47 and passim; Carter, Capitalism, pp. 234235; Richard Hyman, Industrial Relations: A Marxist Introduction (London, 1975); and John McIlroy, "Still Under Siege: British Trade Unions at the Turn of the Century", Historical Studies in Industrial Relations, 3 (1997), pp. 93-I I2. An alternative model is John Kelly, Rethinking Industrial Relations: Mobilization, Collectivism and Long Waves (London, 1998), pp. 9-29 and passim. 
annual conference of delegates (ADC). ${ }^{8}$ It was in response to new groups of members and the need to soothe the concerns of associations merging with the union, that the senior leadership of ASTMS gradually devolved or "dispersed" decision-making to autonomous sections within the organization. Such recruits often had little or no political experience within the British labour movement and, argue Undy and his collaborators, were more familar with in-house company bargaining than the factions which struggled to influence the direction of the union. ${ }^{9}$

Some recent investigations of the relations between trade-union leaders, officers and members have revealed a more complex set of loyalties in which political preferences and personal connections, as well as vested interests, coloured the contacts between officials and their constituents. ${ }^{10}$ The importance of leadership personalities as well as the political orientation of factions within different unions have been identified in the growth of white-collar unions by amalgamation and the recruitment of the unorganized. ${ }^{\text {I }}$ Heery and Kelly have pointed out that the relations established between officers and members expressed the diversity of opinions and attitudes within the wider world of British trade unionism, rather than merely reflecting the structure of these bodies or the tension between paid and unpaid representatives of the workforce. ${ }^{\mathrm{I2}}$ While scholars are paying increasing attention to the role of cultural and political preferences in the building of white-collar unions, there remains a strong emphasis on the formal structures of bargaining and representation in most accounts of the expansion and reformation of these organizations.

This article seeks to provide a fresh interpretation of the leadership provided by Jenkins and his relations with the field officers who were appointed to serve the membership of the new union formed in 1968. Undy et al. persuasively show that unions vary in the extent to which they recruit within and across industries, as well as in their systems of administration. It is also broadly accepted that the bargaining functions of trade unions also derive from, and in turn influence, the technical and historical character of the industries they cover. The scope of bargaining is affected by labour-market qualities, production features, scale of enter-

8. R. Undy, V. Ellis, W.E.J. McCarthy, and A.M. Halmost, Change in Trade Unions: The Development of UK Unions Since the I960s (London, I98 I), pp. 51-59, I54-I 55.

9. Ibid., pp. I I $7-\mathrm{I} 24,203-209,324-326$.

ı०. Edmund Heery and John Kelly, "Full-Time Officers and the Shop Steward Network: Patterns of Cooperation and Interdependence", in Patricia Fosh and Edmund Heery (eds), Trade Unions and their Members (London, 1990), pp. 75-106, 102-103.

i . Chris Wrigley, "From ASSET to ASTMS: An Example of White-Collar Union Growth in the 1960s", Historical Studies in Industrial Relations, 7 (1999), pp. 55-74; Jeremy Waddington, The Politics of Bargaining (London, I995); Sandy Clark, "The Limits of Amalgamation: TASS and MSF, I98I-200I", paper presented to the Labour History conference on "Industrial Relations in the Twentieth Century" (unpublished, Keele University, 2002).

I 2. Heery and Kelly, "Full-Time Officers", pp. I02-103. 
prise, and so on. Historians have often noted that extent to which workers' technical skills and expertise have influenced their bargaining rewards and the collective culture of "craft", though less has been written about the distinctive culture of trade unions and the shared knowledge acquired by field officers who worked for them. Rather than emphasizing the institutional structures of the union, the polarity of officials and members, or the periodic intrusion of political factionalism in directing the progress of the union, this article explains the impact of such characteristics in relation to the accumulated working practices of bargainers and the growth of an intellectual culture within the organization. It is suggested that the historical interplay between members' experience of their employment, usually expressed by lay officers, and the bargaining techniques devised by the paid and unpaid officials who represent them, constitutes the basis for the union's collective culture.

The value of such a cultural resource can be seen in unions where the responsibility for bargaining was devolved to local officials or even lay members, such as the workplace groups which formed the backbone of organization within ASTMS and its predecessor. Another constituent of the internal life of the union is the employment relationship between the union and its own staff, including the fieldworkers who usually form the most influential employees in the pay of the organization. An important aspect of the Jenkins years was the provision of officer training and the presentation of union employment as a career pathway for ambitious, educated individuals who sought a well-paid profession. These reforms were introduced at a period when the leadership of ASTMS also sought to model and market the organization as the natural agent for professional, salaried employees who possessed or aspired to middle-class status. In promoting such modernization of employment practices among the officials, Jenkins drew on historical notions of superior expertise within the union, as well as directing his officers to the massive new market of salaried employees.

It was suggested in a previous article in this journal that the Association of Supervisory Staffs and Executive Technicians (ASSET), the forerunner of ASTMS, had accumulated three distinctive kinds of expertise in the years before the merger with the Association of Scientific Workers (AScW). This knowledge was acquired by both officers and members in their experience of postwar bargaining, usually in the face of bitter hostility from British employers. Bargaining skills and strategies were based on practical reasoning as well as philosophical or political preferences and comprised: firstly, a model of collective discipline derived from craft traditions; secondly, an appeal to professional expertise grounded in the managerial and scientific credentials of technical staff; and thirdly, a quasi-legal approach to bargaining and employment contracts which included a readiness to use the courts as well as press 
for legislative support as a means of securing recognition. ${ }^{\mathrm{I} 3}$ Finding the Trades Union Congress (TUC) reluctant to promote the legal and legislative remedies which would protect the position of white-collar employees, the union continued to pursue the employers in the courts wherever possible. ${ }^{\mathrm{I}}$

Each of these approaches were embodied in the bargaining methods as well as the particular structures developed by ASSET, and they were variously applied in response to the different constituencies served by the union. The most familiar unit of association among members remained the workplace group within the individual plant and among distinct grades of employees. Faced with a diverse and scattered constituency, the National Executive Council (NEC) of ASSET had encouraged the growth of industrial combines to service the employees in larger firms, later introducing National Advisory Councils (NACs) to pool the union's resources in distinct sectors and major enterprises. Before the formation of the ASTMS in 1968, national bargaining was only achieved in civil air transport. Companies such as General Electric (GEC) continued to insist on district settlements for their separate cost centres. ${ }^{\text {IS }}$ Making a virtue of necessity, Jenkins argued that single-firm and plant negotiations were likely to replace agreements with employers' associations in modern industry, though the raison d'être of combine committees and advisory councils was to secure broad, national agreements.

These constraints on the growth of ASSET in the postwar years also shaped the employment and deployment of officers within the union. Faced with the need to maintain a diverse and dispersed membership at some distance from national and regional offices, ASSET periodically debated the virtues of concentrating its recruitment efforts on particular industries (such as engineering, where it drew the bulk of its members well into the 1970s) rather than seeking to cover large geographical areas. In practice, most officers continued to serve one of the twelve or more "divisions" of the country, maintaining close contact with the lay representatives of their Divisional Council and nursing key groups of activists who formed the network of support for the area. The union's key workers were expected to acquire a detailed knowledge of their region as well as a range of industries where members worked, including the

I3. Joseph Melling, "Managing the White-Collar Union: Salaried Staff, Trade-Union Leadership and the Politics of Organized Labour in Postwar Britain, 1950-1968", International Review of Social History, 48 (2003), pp. 245-27I.

I4. Ross M. Martin, TUC: The Growth of a Pressure Group, I868-1976 (Oxford, 1980), pp. 286-288, 355 n. 73 .

I 5. Clive Jenkins, "My Strategy to I975”, Industry Week, 30 January I970, pp. 8-9. Rosemary Crompton and Gareth Jones, White-Collar Proletariat: Deskilling and Gender in Clerical Work (London, I984), p. I68, Table 5.I, gives total white-collar union membership as 5.I million in 1979. ASTMS claimed well over 400,000 members by 1979 . 
technical processes, payment systems, and personal contacts which defined the boundaries of collective bargaining. Officials cultivated their own constituencies in such areas not only as a means of advancing their careers but also as a protective shield when they were attacked by unhappy members, colleagues, and or even by their superiors in the Association. Personal advancement could also be secured through the internal bargaining machinery of the Association itself. Since the late I940s, the executive members of ASSET had negotiated pay and conditions of service with a full-time Officers' Committee (OC) which represented all permanent fieldworkers as both employees and as members of the union. Elected by their peers, the leading figures of the OC claimed a following among the officials and were in direct contact with the salaried and lay leadership of the organization.

The ways in which the officers of the union were recruited and managed in the ASSET years offers some explanation for the character and purpose of factionalism within the ranks of the fieldworkers. It also casts light on the integral links between the institutional culture of particular unions and the political framework of British labour in which officers viewed their role within the world of bargaining. Throughout the postwar period, officials were recruited from the lay activists and officers in the ranks of ASSET and analogous unions, such as the Association of Engineering and Shipbuilding Draughtsmen (AESD later DATA). Among the qualifications which the union required of applicants for employment, before and after the amalgamation with the Association of Scientific Workers in I968, was political experience of the "labour movement". ${ }^{16}$ The broad values attached to the TUC and the Labour Party were shared by fieldworkers but the anticommunist purges in the Cold War era provoked bitter feuds within the officer corps of ASSET, as right-wingers aligned with Catholic Action and insisted on the even distribution of services across the midlands and northern counties, where the reactionaries were powerful. Communists in London drew on the shop stewards' experience of the manual unions in promoting work groups and combine committees in ASSET, while Fabian and Tribune left-wingers, such as Mikardo and John Aplin, remained intent on the recruitment of managers and executives in key sectors of the British economy.

Whereas the pursuit of industry-wide bargaining and plant representation can be attributed to ASSET's origins among the craft trades of the engineering industry, the union's responses to public policy, including its consistent opposition to government incomes policies, drew on different

I6. NEC Minutes, I0-I I April 1976. On complaints from its divisional council in East Anglia at political vetting of candidates in 1976 , the NEC stated that "the job of a trade-union official was a quasi-political one". 
currents within its historic culture. In elaborating their attack on statutory wage controls during the two decades before 1968, ASSET's leaders insisted that salaried staff were particularly disadvantaged by such policies, as differentials were eroded and overtime or piecework was rarely paid. This argument was attached to a broader socialist principle that incomes should not be regulated while prices, profits, and rents went untouched. While making the case for greater rewards for technical and scientific expertise in the management of industry, ASSET pressed for free bargaining and also for legislation to strengthen employment and bargaining rights of staff who avoided industrial confrontations with employers.

After his appointment in 1960 Jenkins committed the union to a rapid expansion of membership as a basis for effective bargaining. Early moves to link up with the Draughtsmen's Association and the Scientific Workers, to forge an alliance of unions serving technical staff, was followed by a series of mergers and recruitment drives which quickly transformed ASTMS into a general union of white-collar workers. In expanding the Association, Jenkins drew on the recruitment practices of earlier years, while refusing to discriminate in favour of particular models of craft organization, scientific management, or legal redress. Recognizing that the term "white-collar" was merely a convenient umbrella for salaried employees, Jenkins expanded his rhetoric and appeal to a wide range of employees. More importantly, the ASSET leader soon realized that the growth of mass communications affected the exercise of social power and offered trade unions a platform by which he could reach a middle- as well as working-class audience. Having developed a repertoire of bargaining skills on claims about the valuable craft skills, the superior technical expertise, and the distinctive contractual status of its members, the ASTMS leadership attempted to maintain a similar balance in responding to legislative reforms affecting trade-union rights after 1968.

The tensions which arose in consequence of the rapid growth of the union, the changes in the constituencies which it served, and changes in government labour law, can be traced in the relations between the leadership of ASTMS and its fieldworkers in this period. By the early I970s, the Association secured mergers with other unions and staff associations by conceding autonomy to distinct sections of members and the officers who represented them. Yet the strains in the structure of the organization were not, in themselves, a serious impediment to the growth of membership or the cooperation of officials with their constituents. The sterile factionalism of the I950s subsided in the early Jenkins era, even though the increasing size of the union led to renewed debates on the appointment of specialist industrial, as distinct from regional, officials. From 1965-1966 the union began to recruit younger, educated fieldworkers with limited industrial experience who were offered basic training 
and a career path within the Association. Field officers in almost every area of the union were able to reach local agreements, or run industrial disputes, with only general approval required before action was undertaken. The most effective officers exploited the mass media to boost the union, and recruitment figures became a key indicator of officers' success or failure, though the good opinion of important lay members and their peers also figured in the advancement of ambitious fieldworkers.

There remained some differences in approach and political commitment among the officer corps after 1968, though this rarely reflected serious clashes between sections of the membership. Most observers agreed that the bulk of rank-and-file members of ASSET and ASTMS were politically more moderate than their officials, though the influx of insurance and finance workers in the early i 970 s prompted leading officers to argue that these employees preferred legal and procedural tactics rather than industrial action. The distinctive bargaining practices and traditional skills devised by the union were alternately favoured by radical or moderate officials, with the former more likely to be employed in manufacturing industries and areas where manual unions were strongly represented. Yet the philosophical underpinnings which enabled the union to maintain its left-wing opposition to incomes policies, while promoting differential rewards for its own members, were not seriously eroded by workplace conflict. It was rather the introduction of new industrial relations law after I 968 which provoked serious controversy and division among the officers, with a majority opposed to the leadership's arguments for registration under Conservative government rules. Growing frictions with the fieldworkers culminated in a major dispute during I 975, when Jenkins and the NEC enforced their management prerogative to dismiss a trainee officer without consultation. The resulting battle led to important reform of bargaining procedures within the union itself, as well as a hardening of political affiliations among leaders and officers. These attachments were unlike the factionalism which had divided the union's workforce in the Cold War period since Jenkins secured the support of both Labour and Communist parties in his struggle with the workforce. More serious was his prolonged and bitter struggle with the ultra-left Trotskyite press and its supporters among the officers.

These struggles left their impress on contemporary and subsequent academic debate about the role of white-collar unions in modern society. Many of those whose analysis of British trade unionism has confirmed the British emphasis on the fundamental impact of institutional and legal structures were key actors in these processes of investigation, commentary, and legislative reform. Leading figures in the debates on union governance, such as Keith Wedderburn and William McCarthy, were closely consulted by Jenkins and ASTMS. In Bourdieu's terms, academic and political commentators have been engaged in the competitive creation of symbolic 
capital and seeking to secure the profits of influence. ${ }^{17}$ This article attempts a detailed analysis of the growth of ASTMS in the period when this institutional and intellectual competition within the union world was at its height, between the formation of the new union and the ascent of Jenkins to power in the wider labour movement during the last days of Labour government in 1979. In discussing the leadership of ASTMS and Jenkins's relations with his fieldworkers, it is argued that there were mounting tensions between the officials as established ways of thinking about bargaining came under scrutiny during the rapid expansion of the union. In contrast to the ultra-left lampoon of Jenkins as a remote bureaucrat, the evidence suggests that the General Secretary and his executive colleagues were slow to devise a system of supervision over the workforce and the general administration of the union remained erratic, at best. Jenkins appreciated the benefits of recruiting younger, educated, and ambitious officers who wanted a professional career similar to those enjoyed by the people recruited to the ranks of ASTMS. Both the established praxis of the union and the intuitive management style of Jenkins encouraged autonomy as well as a competitive, intellectual spirit among the officers. Faced with a serious challenge to their assessment of labour legislation after 1968, Jenkins and his immediate subordinates underestimated the strength of political opposition to any accommodation with reforming governments, and in the longer term Jenkins failed to realize the cost of failing to devise effective systems for the training and management of the officials.

The discussion which follows is organized in two parts. The next section deals with the period following the amalgamation which created ASTMS in I968. It is followed by a discussion of the officers' strike in 1975 and its consequences for the management and political direction of the organization to 1979 .

\section{MANAGING THE GROWTH OF THE UNION, I968-I975}

When working with advertisers to create the images by which his union could appeal to nonunionized staff in the UK, Jenkins had suggested that modern technology represented a threat rather than an opportunity to the isolated employee. ${ }^{18}$ ASTMS was also intent on suggesting that government wage controls had an unfair impact on the position of salaried workers whose differential privileges were steadily eroded as manual workers secured improvements in both pay and working conditions. These

17. Pierre Bourdieu, Pascalian Meditations (Cambridge, 2000), pp. 54-56, I 16-i I7.

I 8. Long before award-winning ASTMS advertising, Jenkins's own publicity emphasized the fear of redundancy among salaried staffs; CJ/4/50/I-5 (1962-1964), Clive Jenkins, "Red Under a White Collar", The Statist, 23 March 1962 and I July 1964. 
initiatives enabled the Association, along with a number of white-collar unions, to build members quickly during the decade after 1968. Jenkins had accurately forecast that the main benefit which the AScW brought to the new amalgamation was a sheaf of agreements which had been negotiated over the decades with a wide range of employers. Here lay much of the potential for future expansion. In recent years there has been considerable debate over the impact of leadership on the postwar growth of the white-collar years. ${ }^{19}$ An important feature of the early years of ASTMS was the way in which Jenkins used the escalation in membership growth to discard many of the former $\mathrm{AScW}$ leaders, and to build a professional officer corps who embodied his own entrepreneurial vision of the organization.

The two unions merged as equals, but ASSET remained the dominant partner, bringing more than 50,000 members, while John Dutton's union could claim little more than 17,000 paid-up contributors. The merged Association grew from 87,000 members in the autumn of I 968 to 97,000 by the following spring and added a further 10,000 in the Autumn of $1969 .{ }^{20}$ Though the new union climbed beyond 100,000 members within the first two years of its existence, the former scientific workers' sections lost or turned over many recruits. ${ }^{21}$ John Dutton assumed responsibility, as Joint General Secretary, for staffing matters within the newly merged union. Within a short period his own position became uncertain, and by autumn 1969 he was actively negotiating his retirement. ${ }^{22}$ The impending departure of Dutton provided Jenkins with an opportunity to consolidate his own authority within the new union, persuading NEC to promote Muriel Turner to become one of the triumvirate of assistant general secretaries, alongside Bob McCusker and Stan Davison. ${ }^{23}$ The NEC also agreed to appoint two more national officers in London, a move possibly designed to pacify the growing number of ambitious divisional officers. There were also signs that the first intake of trainee officers (including Roger Rosewell in Birmingham and Roger Lyons in Liverpool), were seeking promotion and a move to London to advance their careers. ${ }^{24}$

19. Joseph Melling, "Leadership and Factionalism in the Growth of Supervisory Trade Unionism: The Case of ASSET, 1939-1956", Historical Studies in Industrial Relations, I3 (2002), pp. 37-82.

20. NEC Minutes, 4-5 May I968; 25 August 1968; 9 March 1969; I I October 1969. August 1968 membership was 85,945 (revised to 87,652), a net gain of 10,000 on the year to October 1968. 21. NEC Minutes, 23 November 1968, I3 April 1969.

22. NEC Minutes, 9 August 1969, I4 February 1970, I4 March 1970. General Purposes and Finance Session, 9 August 1969, I3 September 1969, i i October 1969.

23. ASTM NEC Minutes, 27 January 1968, i I April 1970. Stan Davison had been Assistant General Secretary of the AScW, McCusker being Jenkins's deputy. Muriel Turner was subsequently given responsibility for finance members.

24. $79 \mathrm{AS} / 3 / 3 / 33$, Bird to Dutton, I3 May 1969, Jenkins to Bill Webb (latter of Officers Committee), ro July I969, Rosewell to Jenkins 4 July I969, Jenkins to Rosewell 9 July i 969. Bird 
As the retirement of Dutton approached, Jenkins assumed a more active role in staffing questions, negotiating the delicate subject of trainee officers with Reg Bird, now Secretary of the ASTMS Officers' Committee. Under pressure from officers in the West Midlands and elsewhere, the Committee imposed a policy of noncooperation with trainees from spring 1968, in support of their demand for full-time appointments rather than probationers. This ban was lifted the following summer as the NEC promoted some ambitious officers. By early 1970, the former AScW lay officers on the National Executive expressed alarm at the rapid eclipse of Dutton. In a belated effort to assert some control over the direction of officer relations, the NEC discussed the appointment of trainees with the Officers' Committee and decided to review the "general structure of the Union". ${ }^{25}$ As union membership rose towards I 50,000 in summer 1970 the NEC appointed Reg Bird (Secretary of the OC) and Roger Lyons as national officials amid further promotions.

The growing confidence of the union and its bargainers was also reflected in the rapid spread of industrial action in districts such as the West Midlands, where left-wing officers built their contacts with local activists as well as seeking to impress the NEC with their recruitment returns. ${ }^{26}$ As the officer workforce expanded and it became increasingly difficult to monitor industrial disputes, Jenkins assigned his assistant GS, Bob McCusker, to manage the field staff and sanction any strikes. The difficulties of maintaining control over disputes and the officers were most apparent in the West Midlands, where frictions culminated in the departure of the erratic Rosewell after the celebrated Pilkington dispute. ${ }^{27}$

to Dutton, I 8 July 1969 with notes of meetings of 2 I February 1968 and 6 March I968. Minutes of OC at 29 July I 968 . Bird to Jenkins, 6 August I 969 . Bird to Dutton, I 3-2 I October and 3 November 1969. Dutton to Jenkins 3 I October 1969. Typescript, (n.d.) apparently proposals of the OC regarding trainee officers. The rise of the ambitious Lyons was jeopardized when he incurred the severe displeasure of Jenkins when seeking selection (without union permission) as a Labour candidate for Liverpool Wavertree; NEC Minutes, I 2 July-13 September 1969.

25. NEC Minutes, I4 February I970. The OC officers: Bird, Owen Smith, Bill Webb, and Ted Mackenzie. The first two were Communist Party members.

26. NEC Minutes I 2 July 1969, I 3 September 1969, 8 November I969, i i April I970, 20 June I 970 , I 2 September 1970. 79/AS/3/3/33 Dutton to Tim Webb, I7 September 1969 and Webb to Dutton 20 September 1969.

27. NEC Minutes, 8 November 1969, I 4 November 1970. 79/AS/3/3/33, McCusker to Jenkins, 26 August 1969, Jenkins to McCusker, 27 August 1969, confirming the latter's responsibility for managing field officers. No 3 Divisional Council Minutes, 79/AS/r/23/ı6: Roger Rosewell's Reports for 20 December I 968-i9 January I969, and I4 June I970-i 8 July I970, for a flavour of his Trotskyite style; Don Groves, Report for 21 September 1969-10 October 1969. Jenkins agreed Rosewell's move to London prior to his irregular role in the unofficial strike at Pilkingtons, leading to charges of "industrial misconduct". Charles Crabb, secretary of the Midlands Divisional Council, replaced him; 79/AS/I/23/I6, No. 3 Division Council Minutes, I 9 October-19 December 1970. 
The intense frictions which arose in the ranks of the West Midlands officers were often the result of strong personality clashes and political differences, but they were also expressed in distinct approaches to the conduct of negotiations and disputes. ${ }^{28}$

The NEC found that as the union grew in size and the confidence of members increased in 1968-1970, there were growing demands from different branches for "guerrilla stoppages" and unapproved strikes against recalcitrant employers. In unprecedented scenes of unofficial action, ASTMS members took part in campaigns to occupy plants such as the Trafford Park works of GEC-English Electric. Officers who enthusiastically supported their members to engage in disputes to gain an advantage against their employers found that the London leadership was frequently less convinced of the need for militant action, souring relations with fieldworkers as well as groups of employees who were facing bitter battles in engineering and car factories. ${ }^{29}$ The wave of workplace unrest which swept the membership in the early years of ASTMS also opened up an important divide between senior officers and radicals who dominated divisional councils (DC) such as that in the West Midlands. Jenkins and his assistants, Muriel Turner, Stan Davison, and Bob McCusker were anxious to secure recognition and long-term agreements with leading firms. Industrial activists often pressed for greater involvement in the bargaining process, as when the West Midlands DC urged the NEC to establish a National Advisory Committee (NAC) to coordinate members in the different plants employed by Arnold Weinstock's GEC-AEI-EE conglomerate. ${ }^{3 \circ}$

As membership leapt in the years following the merger, fuelled by the promises of effective bargaining to restore eroded earnings and protect jobs, the union struggled to contain the militant expectations of its regional activists. Jenkins and the NEC resisted calls at the I97 I conference for an increase in the number of divisional councils, and opposed the

28. NEC Minutes, I 4 July I968, I 2 January i 969 ; ASTMS, 79/AS/3/8/80, Groves to Jenkins, 5 March I975, McCusker to Jenkins 2I March 1975, indicates antipathy between Mathison and Groves.

29. NEC Minutes, I9 May I968, i I October-8 November 1969, I 2 September 1970 for Standard Triumph, the planned occupation of Trafford Park (which the NEC helped to quash), Dunlop, and Lucas. Rosewell was prominent in the unofficial stoppage at Lucas. Bird complained about lack of NEC support at Dunlop, while the Hawker-Siddeley members were "calling for guerrilla-type dispute action in support of a salary claim". McCusker and Wells made a trouble-shooting visit to Rootes, where McCusker acknowledged "relationships with the membership at Rootes plants were not what they should be"; NEC Minutes, Io January I970, I 4 March I 970 for NEC visits to Linwood and bitter recriminations of members over strike pay. 30. NEC Minutes, I3 December 1969, in April-20 June 1970. The NEC decided General Electric should have a combine rather than national advisory council, quashing the efforts of the Midlands Divisional Council to appoint its own NAC; John Fisher interview, 6 August 2002. 
proliferation of advisory councils under divisional control. $3^{3 \mathrm{I}}$ Even so, the number of advisory councils and combines continued to rise rapidly in the early i970s. The five national advisory councils and twenty-one combines of 1970 expanded to forty combines and national advisories. Distinctions between them also blurred. After a brief respite, numbers grew again in 1974-1975, as the NEC nominated chairmen for fifty-three NACs across a wide range of sectors and firms. The Advisory Councils were usually served by a DO as secretary, though there was also a growing tendency for "seconded representatives" to assist the work of the NAC.32

The resentment of some of the ASTMS leadership at the treatment of John Dutton was more visible among Communist Party veterans who attempted to restrain Jenkins, though support from Ian Mikardo and Len Wells enabled the General Secretary to ride out the animosity of the old guard. It was not until the appearance of the Trotskyite Ian Gibson as the NEC member for East Anglia in I97I that Jenkins and his allies had their first taste of a vigorous assault from the ultra-left which coloured union politics throughout the I970s. ${ }^{33}$ Loyalists such as Mikardo and Hoyle sought to exclude Gibson from office after his disclosure of confidential discussions concerning members on strike. ${ }^{34}$ Gibson's position was protected by his effective leadership of successful work-ins against the closure of shoe factories in Norwich, though matters came to a head in the summer of $\mathbf{1 9 7 4}$, as the Jenkins and Turner bitterly attacked the misrepresentation of their policies in articles the Norwich activist wrote for Socialist Worker. 35 The Appeal Court accepted the right of members to criticize "the policy and leadership of the Association" but decided that Gibson be excluded from office for five years. ${ }^{36}$

31. NEC Minutes, 9 March 1969, 20 June 1971. The 1971 Annual Delegate Conference proposed sixteen rather than twelve divisional councils, opposed by Jenkins who saw potential challenges to NEC.

32. NEC Minutes, I0 June 1972, I4 June 1975. The salaries of seconded members were usually paid by the employer as they filled a role comparable with that of the convenor of shop stewards in manual unions.

33. Ian Gibson replaced Bert Brown as the representative No. 5 Division (East Anglia). Lancashire returned the Catholic Action supporter, Jack Williams.

34. NEC Minutes, 9 June 1973 for Hoyle. Len Wells, Lionel Jacobs, Charles Fulton, Arthur Sier, and Bert Brown were Communists or fellow travellers who usually supported Jenkins.

35. NEC Minutes, I 3 November 1971, 8 January 1972, I I March 1972, I 2 August 1972, 9 December 1972, I2 January 1974. Gibson's adversary was Albert Edmondson of Castleford, though Muriel Turner also complained about the Trotskyite circular "ASTMS Action", as well as Gibson's proposal that members in dispute at Associated Containers Transport close down their refrigerators; NEC Minutes, Io May-8 June 1974.

36. NEC Minutes, I3 July 1974, 7 September 1974, 9 November 1974. Reg Bird and Ian McEwan were called as witnesses against Gibson (Bird and McCusker being also attacked in Socialist Worker). Mikardo led the hard-liners against Gibson while Communists, Audrey Hunt and Bert Brown, favoured leniency. Jenkins later pursued Gibson for breaches of union rules, the NEC being reluctant to press the point; Ian Gibson interview, 22 April 2002. 
There were not only tensions between senior officials and their subordinates as the leadership of the union attempted to maintain control of bargaining strategy and to manage the ambitions of the workforce. Leading officers also differed in their approach to recruitment priorities and method of negotiation. These were often differences of practice rather than principle, but they drew on the different currents of bargaining experience within the union. McCusker retained something of Len Powell's earlier perspective on industrial discipline, drawn from the experience of craft unions in the engineering trades, and sought compromises in the settlement of interunion disputes, if only as a prelude to conciliation at the TUC. Stan Davison brought the more erudite assumptions of the AScW to his negotiations with major employers in scientific and technical trades, emphasizing the professional status of his members as he cultivated relations with senior executives of major corporations. The legalist-procedural emphasis in union policies was greatly strengthened by Muriel Turner's long acquaintance with legal advisers to ASSET, and her conviction that ASSET's historic reliance on branch and divisional activities was not appropriate in organizing the large single-firm membership of the financial sector. A more formidable intellectual than her immediate colleagues, Turner contrasted the deliberative approach of the white-collar unions with the customary appeal to solidarity on which the power of the craft unions rested. ${ }^{37}$

These different outlooks and methods of bargaining were broadly associated with distinctive constituencies of members within the ranks of ASTMS. The changing profile of the Association in the early i97os accentuated the divergence in the models of bargaining pursued by senior officers. Jenkins and his lieutenants favoured rapid building of members by acquisition of staff associations, often with significant concessions to their perceived interests and autonomy. ${ }^{38}$ The decline of the notorious Foremen's Mutual Benefit Society followed the passage of private legislation framed by the union in 1968 , relaxing the grip of the engineering

37. Muriel Turner interview, 29 October 1998; "Now Danny McGarvey [Boilermakers' Society] of course was the sort of old-style union official who never bothered with research, never bothered with negotiations. [...] Now the realities on the ground in financial services in the 70 and 80 s were very different. [...] [T] here you had a membership, or potential membership, that was legalistic oriented. They wanted laws that they could use, recognition laws that they could use. I mean McGarvey would never have bothered about laws on recognition would he? [...] You only want laws on recognition when you are dealing with a lot of people who believe in that sort of thing." Turner championed the move from branch meetings to intra-firm meetings, in deference to the historic culture of the insurance members attached to in-house associations.

38. NEC Minutes, 27 October 1968, i I July 1970, 9 November 1974. Staff associations joining ASTMS in 1970 included Pilkingtons and BICC, the NEC giving "special attention to the assimilation and integration of staff associations". Stan Davison and Roger Lyons pursued ICI, Davison achieving the entry of ICI's staff society in 1974 . 
employers on their supervisory and administrative staff and enabling engineering supervisors to join ASTMS in substantial numbers. There was also the major influx of members from insurance and financial services, following an initial approach to ASTMS by the Prudential Staffs Association in 1970.39 Within a few months a crowd of company associations had joined, along with the Union of Insurance Staffs led by Maurice Reynolds. Jenkins often won over the leadership of such associations by offering them employment in the union, Reynolds becoming "National Secretary" of the Insurance Staff Section and while the separate identity of this group gradually faded, many of the separate companies and occupations retained their sectional rights within the constitution of the union..$^{40}$ Jenkins's aggressive pursuit of expansion also led him to make an ill-advised foray into the banking sector with the admission of members of the Midland Bank Staff Association. One consequence was a further deterioration in relations with the National Union of Bank Employees (NUBE) and its dynamic leader, Leif Mills, which blighted cooperative action among these unions for many years. ${ }^{4 \mathrm{I}}$

Senior officers, such as Muriel Turner, argued that the culture and class orientation of the new recruits required a distinctive approach to their organization and governance. Turner made fresh arrangements for the membership in financial services on the grounds that the traditional system of work groups, branches, and divisional representation had little relevance to these employees. Recruiting staff in the financial heartland of the City of London, Turner sought to distance the union from images of militancy in manufacturing industries remote from the capital. $4^{2}$ Such an interpretation of the new recruits was not shared throughout the officer ranks. Those recruiting finance workers in provincial centres often faced bitter opposition from the major insurance firms, such as Cooperative Insurance and the Royal Liver in northwest England during 1973-1975, and fought hard to nurture confidence among female workers who were

39. NEC Minutes, I I April-20 June 1970, noting the membership of 3,500 and scope for 6,000; Clive Jenkins, All Against the Collar: Struggles of a White Collar Union Leader (London, I990), pp. II3-II6.

40. NEC Minutes, I2 September-Io October 1970, I4 November 1970, 9 April 1972. The UIS brought 17,000 members, Joan Mineau becoming Reynolds's assistant following a favourable merger vote of I0,92I to I,I74. Other insurance additions included the Royal Group, the Guardian Royal Exchange, Norwich Union, and General Accident. Their continuing autonomy within the constitution is evident in the Rules of the MSF Union, January 1999, pp. 34-53, Section Rules.

4I. NEC Minutes, 8 September 1973, I2 January 1974, 8 February 1975, Midland Bank Technical and Services Staff. Robert Taylor, The Fifth Estate: Britain's Unions in the Seventies (London, 1978), pp. 276-279, for Jenkins and Leif Mills of the National Union of Bank Employees.

42. Muriel Turner interview, 29 October 1998. 
"quite new to any form of militant activity, [though] their support had been total and enthusiastic".43

These different preferences for recruiting and retaining members were also paralleled by divisions among the officer corps in attitudes towards bargaining within the union itself. Jenkins and the executive were slow to create a hierarchy of management which could coordinate the field workforce as the union expanded. ASTMS membership continued to be administered on a regional rather than sectoral basis, though the admission of groups such as insurance staffs weakened the rationale for geographical coverage by officers. Questions were raised when the NEC proposed that the grade of national officer be given responsibility for larger regions and also particular sections of the membership, including the insurance staffs recently recruited. ${ }^{44}$ Senior figures such as Reg Bird (former Secretary of the OC and now national officer for the National Health Service) argued that divisional officers should be allocated to particular groups and sectors, acquiring the expertise necessary to undertake a complex range of negotiations. Traditionalists such as Bob McCusker complained to Jenkins about the neglect of the industrial and manufacturing trades which still formed the backbone of ASTMS.45

This was the context in which the issue of officer training returned to the agenda of collective bargaining between the NEC and the Officers' Committee. It was agreed to progress trainees from their probation to the post of "industrial officer" with advancement to the grade of divisional officer dependent on satisfactory service, the availability of employment, and the consent of the local divisional council. ${ }^{6}$ Discussion of these proposals were coloured by the growing animosity between the leadership and its ultra-left critics as Ian Gibson and other NEC members challenged

43. NEC Minutes, 8 January 1972, I2 February 1972, 8 December 1973, 8 February 1975, I 4 June 1975. Bob Howard and Brian Fox (both based at Liverpool), negotiated the entry of the Royal Group and Royal Liver respectively. Hazlewood, responsible for the Cooperative Insurance Society, reported in 1975 it "remained one of the most obdurate managements in the industry".

44. NEC Minutes, 8 December 1973, I I January I974. The NEC agreed to the appointment of four national officers, two in London and two in the provinces, with their responsibilities to be decided after consultation with the Officers' Committee rather than (as Jenkins had wanted) than prior to any such discussions.

45. 79/AS/3/8/80, "C.J. Secretary Correspondence, I974-1975"; memo of McCusker to Jenkins 7 August 1974, in response to Bird's memo regarding NHS work: "I do feel I must emphazise to you again that our traditional membership, especially in engineering and chemicals, are being under-serviced because of the tendency of the Association to regard new areas of recruitment as requiring special servicing”. Undy et al., Change in Trade Unions, p. I48, Table 26, indicates that that 160,000 or 53 per cent of ASTMS members were still employed in engineering trades in December 1974, followed by 35,000 or I 2 per cent in insurance and banking.

46. NEC Minutes, I3 February-3 April 1971, 8 January 1972, 9 April 1972. Discussions concluded with the advancement of industrial officers and trainees. 
the activities of Jenkins and the Officer Coverage and Selection Committee (OCSC) during 1974. The officers were represented by their own $\mathrm{OC}$ and demanded greater access to internal union reports, including detailed financial information. With almost soo bargainers now employed, the OC also argued that the NEC should lift its embargo on their standing for election to government office. ${ }^{47}$

These contacts between officers and the leadership of ASTMS reveal the tensions created by personal and political loyalties within the ranks of the union. The Tribunite leadership of ASSET's NEC forged an alliance with leading communists on the $\mathrm{AScW}$, as a new generation of Jenkins loyalists (such as Russell Kerr and Doug Hoyle) were drawn into the leadership and actively supported in their parliamentary ambitions, while right-wingers and recalcitrant leftists who opposed the union's traditional policies on wage controls and free bargaining were steadily marginalized. $4^{8}$ Carter has argued that the Tribunite rhetoric of the ASTMS leadership had little impact on the broad mass of its members, though it would be more accurate to say that Jenkins and his allies used these allegiances to politically manage the union. It is also fair to note that contemporary efforts by Labour governments to control prices and incomes, as well as to regulate trade unions, confronted even socialist officers with difficult choices. ${ }^{49}$ Jenkins's resort to the civil courts in seeking to overturn such regulatory policies again drew on the accumulated expertise of the union, earning the applause of the British left and the deep displeasure of moderates on the TUC General Council..$^{\circ}$

ASTMS and its officers were celebrated for their capacity to breach government wages policies in the I960s but found more difficulty in uniting around a common response to the new labour legislation introduced after 1970. Having attacked Barbara Castle’s "In Place of Strife" and Labour proposals for union reform during 1969, the NEC initially criticized the TUC's cautious response to Conservative moves to compel legal registration of unions. ${ }^{\text {I }}$ When Congress decided at Croydon that it

47. NEC Minutes, 8 June-7 September 1974.

48. ADC Minutes, Hove, I963. Parliamentary candidates included David Ennals, Doug Hoyle, Peter Jackson, Russell Kerr, and Robert Maxwell. Among the Communists arriving from the AScW who were critical of Jenkins at some point were Frank Cope, Arthur Dent, Audrey Hunt, Lionel Jacobs, and Arthur Sier. Len Wells and his protégé Stan Davison also carried Party cards at different times in their union careers.

49. Carter, Capitalism, Class Conflict, pp. 196-97 and passim; ASTMS Division I Minutes, I 3 July 1968, notes Jenkins's Tribune defence of Jim Mortimer's membership of the Prices and Incomes Board.

50. NEC Minutes, 3 August-8 October 1966, including the Thorn Electric case at Edmonton County Court. The NEC resolved "to use every constitutional means at its disposal, through the machinery both of industrial relations and the law, to protect the traditional trade union rights of collective bargaining". Also 79/AS/3/9/7, Jenkins correspondence with Mikardo: Mikardo and Orme to Jenkins, 29 December 1967 and 4 January 1968. 
would require all unions to deregister under the industrial relations legislation, however, Mikardo and Jenkins persuaded the NEC to delay any decision until the union's own conference could "help us to make up our minds finally".52 After attempting to persuade the officers and conference delegates to register under the Heath legislation, Jenkins and his NEC lost key votes and faced bitter criticism for their vacillation over the rule changes required to opt out of the legislation. ${ }^{33}$ Prominent among those officers arguing for registration under the new Act was Muriel Turner and some of the officials with connections to the finance membership, who preferred the procedural and quasi-legal approach to employment rights which ASSET had developed since the I940s. In contrast, most officers working in manufacturing centres, where the confidence and support of manual unions had frequently been secured by patient groundwork, were firmly opposed to breaking ranks with the TUC. 54 Relations with divisional councils were similarly strained as the NEC hesitated over the necessary rule changes in I97I-I972, while the union clashed with the left-wing draughtsmen's union, TASS (formerly the AESD and DATA), over its attendance at the Industrial Relations Court (IRC) in the important dispute at C.A. Parsons.5 While ASTMS called for the replacement of the current labour laws by "a sensible legal framework for legitimate trade union action", the TUC endorsed Hugh Scanlon's total boycott of the IRC, and Jenkins faced a barrage of attacks in the left-wing press as well as from divisional councils where radical officers were ascendant. ${ }^{56}$

The debacle of the Industrial Relations Court and the decisive defeat of

51. NEC Minutes, 27 January 1968, 9 February-I I May 1969. The NEC declared its "total opposition to this authoritarian attitude" of the Castle proposals; Minutes, Io October 1970-3 April I97I.

52. NEC Minutes, 6 June I97I, where Jenkins presented a letter from the President (Mikardo) that the NEC should wait for further ASTMS and TUC conference discussions before reaching a view. At least one member of the NEC asked for permission to oppose this policy from the rostrum but Mikardo refused; NEC Minutes, I 8 June I97I.

53. NEC Minutes, I4 August-I I September 197r. Groves interview I3 March 2002. Among Jenkins's anxieties was that ASTMS would lose members to competitors which registered. 54. NEC Minutes, 9 October-I 3 November I97I. Senior insurance officers were criticized for issuing a circular in contravention of $197 \mathrm{I}$ Conference decisions. Turner interview, 29 October I998: "The whole thing, in my view, was quite mad, and I said so at the time. But nobody listened." 55. NEC Minutes, 9 October-I I December I971, I I March-5 May I972, I0 June-9 September 1972. Jenkins engaged in a protracted and fruitless correspondence with the Industrial Relations Registrar as well as negotiating with the Commission on Industrial Relations (established by Labour in 1969) while advising the TUC that ASTMS would defend itself before the IRC in the Parsons case until the TUC compelled TASS to discuss matters. The NEC divided when Sier supported the TASS line.

56. NEC Minutes, I3 November 1971, I2 February-i I March 1972, I 2 August 1972. Jenkins withdrew advertising from Tribune after a scathing commentary was published; interview with Richard Clements (former Editor), 23 February 2002. 
the platform at the 1972 ASTMS conference revealed the limitations of the political dominance of the Tribunite left and the capacity of Jenkins to manage the political sympathies of his officers. The most visible and virulent critics of the ASTMS leader were the Trotskyites, who had been favoured by Jenkins in the early I960s but by 1970 were his bitter adversaries. ${ }^{57}$ The ultra-left exerted an influence at union conference out of proportion to their numbers, but they were far less numerous and influential than either the Labour Party or Communist Party in the ranks of both members and officers. By the late ig6os communist activity and influence on the shopfloor of British industry was in clear decline, yielding space and some influence to the workerist politics of the ultra-left. Bert Ramelson and the Industrial Department of the Party still retained a remarkable sway in many manual and white-collar unions. ${ }^{58}$ Sceptical of the claims made by Jenkins and others for the salaried employees as the new white-collar working class, Ramelson and senior communists were keen to preserve the Party's influence with the ASTMS leader as a rising left-winger in the TUC and leading opponent of wage controls. 59 The communists also enjoyed a resurgence of support among field officers in the blue- and white-collar unions during the crises of the Heath government, though most senior former communists (including Muriel Turner) were now firmly committed to Labour politics. ${ }^{60}$ The decision of the Heath government to resort to wage controls at the end of 1972 allowed Jenkins to restore some of the authority lost during two bruising years. Tensions with the TUC did not disappear, but ASTMS moved to safer ground as the Conservatives steered Britain into a State of Emergency during the winter of $1973-1974 \cdot{ }^{61}$ After briefly expressing solidarity with the striking coal miners and their wage claim, Jenkins reiterated his familiar demand for free bargaining by the time Labour was returned to office. $^{62}$ In an extraordinary stroke against the powerful Jack Jones

57. NEC Minutes, I2 September 1970. After Rosewell's departure in 1971, International Socialists included John Fisher, Mike Teague, and Dan Sequerra; interview with John Fisher, 6 August 2002; interview with Mel Read and Mike Teague (Leicester), I9 October 2002.

58. Matthews Papers, Communist Party Archives, National Museum of Labour History (NMLH) CP/Ind/Matthews/04/04, 06, 0705/10 and I I, for the limited progress of Industrial Department analysis of industrial work and amalgamations between I948-1954 and I974-1976; Ramelson Papers, CP/Ind/Ram/r i/o2, "Trade Union Amalgamations", and "Notes on Some Amalgamation Problems". Also Julie Jacobs (brother of ASTMS NEC member, Lionel Jacobs), Comment, 6 September 1969.

59. Ramelson Papers, NMLH, CP/Ind/Ram/02/20, notes for North West Industrial School, September 1972, "Class Struggle in Britain", and "T[rade] U[nion] Militants and the Law", November 1972.

60. Bert Ramelson, Carr's Bill and How to Kill It was extremely influential; Turner interview, 29 October 1998, for the "incredibly influential" Ramelson: "We were having this terrific row with the AEU and I knew he had a lot of clout with the AEU."

6r. NEC Minutes, I 8 November 1972, Io February 1973, 8 September 1973, I 2 January 1974. 
(General Secretary of the Transport and General Workers' Union and architect of the Social Contract) and his TUC allies, Jenkins dismissed calls for a flat-rate wage increase across industry as an erosion of differentials and "career prospects for working people". ${ }^{63}$

The introduction of labour legislation by the Conservatives had provoked open friction among the ASTMS officers and a serious challenge to the leadership of Jenkins and the NEC at annual conference. These struggles reflected a deeper tension between the different goals pursued by the union after its formation. The ASSET bargaining methods derived from craft discipline, technical expertise, and legal deliberation were devised as defensive responses to the difficult climate of the postwar and Cold War years. Early attempts at coordinated action by the technical unions proved less important than the amalgamation of 1968, which confirmed the movement of white-collar unions from the defensive positioning of the I950s to the open manoeuvres and competitive recruitment of the I970s. ASTMS's rapid evolution into general union for nonmanual staff did not mean the uprooting of established practices, but extended the Association's appeal to new groups with few traditions of trade unionism. Jenkins often presented his various initiatives, including the recruitment of trainee officers, as calculated management reforms, though the officer corps remained overwhelmingly industrial and masculine in its orientation as well as composition. One of the ironies of these years is that this scientific and managerial union remained an underdeveloped and idiosyncratic organization which benefited from a series of opportunistic initiatives and agreements. Always a brilliant entrepreneur, Jenkins remained a poor administrator and an erratic manager. These limitations in the union leadership were vividly exposed as officer relations rapidly deteriorated after $\mathrm{i} 974$.

\section{THE ASTMS OFFICERS' STRIKE AND ITS AFTERMATH,}

$$
\text { I } 975 \text { - I } 979
$$

By 1975 the ASTMS workforce was widely considered to be among the most literate, ambitious, and best-rewarded team in British trade unions. Younger females formed one of the groups being quickly recruited to the ranks of the union, and women were employed as field officers from i 968. Rather than relying on election by members or promotion by seniority,

62. NEC Minutes, I2 January 1974, with agreement that ASTMS would not use the pay concessions to miners and railwaymen as the basis for further salary demands: "If comparisons are to be made, we would sooner have miners at $£ 50$ per week than stockbrokers at $£ 50,000$ a year"; also Minutes, I9-20 April 1974; cf. Minutes, I9 July I 974 and 7 September 1974.

63. NEC Minutes, I4 June-I2 July i975. Jenkins was now on the TUC General Council; Martin, TUC, pp. 310-31 2. 
the NEC and Jenkins each protected their prerogatives and their influence over the advancement of officers. The NEC retained formal control over appointments, with the General Secretary in attendance at interviews, though his close connections with such senior figures as Mikardo, and later Hoyle, ensured that his preferences were registered in promotions. It was in regard to the management of trainees that the Association became embroiled in a bitter dispute over the effective dismissal of a female employee during the summer of 1975. The consequence was an unprecedented strike of the field officers, who proceeded to picket their own union buildings and openly attacked Jenkins's leadership style in a series of national newspaper briefings. In the longer term, this bitter conflict forced the NEC to reappraise the management of its officers as well as the system of appointment and training which had evolved since the ASSET days.

The immediate source of the struggle was the decision of Jenkins to terminate the employment of Judith Cotter after her probationary service of six months was complete. Cotter had been assigned to work with Terry Comerford in London after starting work in early 1975. After Comerford submitted a critical report on her work, Cotter was formally warned by McCusker (who retained overall responsibility for directing the officer workforce), who recommended to Jenkins that her probation be extended for a further six months. ${ }^{64}$ Jenkins reviewed the case, including highly personal details of a relationship with another officer, and decided on her dismissal along with disciplinary action against her colleague. ${ }^{65}$ At this point the secretary of the Officers' Committee (OC), Don Groves, was alerted and immediately protested to Jenkins and Officer Coverage Committee, insisting that Cotter be reinstated pending a full enquiry into her case. ${ }^{66}$ Jenkins simply asserted his prerogative to manage probationers

64. Gary Morton Papers [hereafter GMP], "Statement by ASTMS National Executive Council to the Chairman and Members of the Committee of the Arbitration in the case of Ms Judy Wright (née Cotter), I September 1975", [hereafter "NEC Statement"], pp. 2-3; memo from Judy Cotter to McCusker, I4 January 1975; letter Jenkins to Cotter, 27 January 1975; memo from McCusker to Cotter, 5 March i 975.

65. The officer was Morton. GMP, NEC Statement, s (iii) "Comerford submitted a very detailed and critical oral report on Ms Cotter to the General Secretary on I 8 June"; Appendices 2 and 3; memo Cotter to McCusker, 23 June 1975 and McCusker to Jenkins, 4 July 1975; letter Jenkins to Groves and Alf Stubbs, Secretary and Chairman of the Officers' Committee (OC), I 8 July i975; memo McCusker to Morton, Io July I975; letter McCusker to Jenkins, I I July i975; memo Morton to OC, $\mathrm{I}_{3}$ October 1975.

66. Stubbs was elected to the chair of the OC on Mackenzie's resignation in protest at industrial action; NEC Minutes, I I January 1975 for Mackenzie, Groves, and Lyons. For Comerford see GMP, Morton's ms notes of Officers' Group (OG) meeting dated 30 August 1975 (this meeting appears to have actually taken place on 30 July 1975), where Comerford complained that "he was being grilled by Officers' Comm[ittee]"; interview with Alf Stubbs (Cheadle), I9 October 2002. Friction between Muriel Turner and the OC led to her exclusion from the OG after refusing to follow any industrial action resolved upon. 
under the terms of their contract and declared himself "totally unwilling to accept alternative judgements, appeal or representations in [cases of] breach of contract". He did concede that he would provide the OC with a written explanation of his decision, stressing Cotter's lapses in personal conduct rather than questioning her professional competence. ${ }^{67}$

Little progress had been made when a meeting of the whole officer workforce or "Officers' Group” (OG) resolved on sanctions in late July, including industrial action, if the NEC refused to reinstate the trainee pending a full investigation. ${ }^{68}$ As the NEC steadfastly refused to reinstate Cotter or allow her to refer her case to the union's appeal court, a report in The Financial Times described the conflict as "the culmination of a growing rift" between the leadership and officers of the union. ${ }^{69}$ In the face of preparations for a full strike at the beginning of August, the NEC belatedly offered binding arbitration on the case, though this failed to halt industrial action or prevent the souring of relations when a further meeting was cancelled by the OC at a few minutes notice. ${ }^{70}$ As the strike progressed, senior officers began to break ranks as McCusker fiercely denounced the handling of negotiations by Groves and the OC at an OG gathering on II August. ${ }^{71}$ Almost one-third of the field officers voted against prolonged industrial action, with opposition to the strike expressed by some seasoned members of the Communist Party, including Reg Bird (a former secretary of the OC), as well as Labour loyalists who supported Jenkins. $^{72}$ In the face of dwindling support, the OC representatives came to terms with the NEC and agreed to refer the case to arbitration by W.J. McCarthy, though the end of the strike in mid-August was again overshadowed by rival press releases and accusations of bad faith as a

67. ASTMS, 79/AS/ı/8/6, GPFC Minutes, I I-I 2 July 1975; GMP, Jenkins to Groves and Stubbs, I 8 July 1975. Jenkins claimed of the affair, "the deepter [sic] one probes the more unsatisfactory it becomes"; Groves to Jenkins 23 July 1975; circular by Wells and Jenkins to officers, 3 I July 1975 .

68. GMP, "Chairman's Report to the Parties by Dr W.E.J. McCarthy", p.I3, §3I; memo McCusker to Stubbs and Groves, 28 July 1975.

69. GMP, letter Groves to OG Members, 3 I July 1975, re Cora Hotel meeting; Financial Times, 3 I July 1975; Morning Star, I August 1975; Groves interview, I3 March 2002.

70. GMP, draft NEC Minutes, I August 1975. The approved minutes appear to have been heavily edited, excluding details of a vote (lost 8 to I 2 ) in favour of extending Cotter's contract. NEC Minutes, 9 August 1975, for the narrow majority 9 to 7 to approve the edited minutes of I August as an accurate record. The minutes also record strong criticism of Groves for failure to refer offer of arbitration and "publication of the facts" to his colleagues and for cancellation of a key meeting with the NEC; memo McCusker to Groves 4 August 1975; Turner interview, 29 October 1998 .

7I. GMP, circular letter from Hoyle, Mikardo, Jacobs, and Jenkins, 7 August 1975; statement from OC 6 August 1975, with addendum dated 7 August 1975; NEC Minutes, I I October 1975. Greta Karpin was warmly commended by NEC for her role in the strike.

72. GMP, Morton's ms notes on the meeting of i I August 1975. The vote for continued action passed 46 to 21, Mackenzie denouncing the "unnatural act we are performing". 
bitter wrangle erupted over the amount of pay to be deducted from the strikers. ${ }^{73}$

McCarthy opened the arbitration hearing in early September and reported a month later. ${ }^{74}$ Jenkins defended his prerogative in regard to the employment of trainees, while justifying his censure and dismissal of Cotter in terms of her lapses in personal conduct rather than professional abilities. ${ }^{75}$ The OC responded by criticizing the training scheme, including the exclusion of probationers from the protection of the procedure agreement for field staff. ${ }^{76}$ In delivering judgement, McCarthy avoided the complex ethical and procedural questions raised by the case, deciding to base his findings on an assessment of the witnesses. ${ }^{77}$ McCarthy vindicated McCusker's version of events and concluded that Cotter's "over-casual" approach to her responsibilities justified Jenkins's termination of her contract, though five months salary was awarded in acknowledgement of the lapses in the union's training. The report also suggested improvements in the supervision of probationers and the representation of trainee officers. ${ }^{78}$

While the NEC and OC each accepted McCarthy's findings, relations remained tense as the officers pressed for discussion of reforms proposed in the adjudication. ${ }^{79}$ The battle continued as the NEC and officers fought to secure the support of divisional councils for their stand. ${ }^{80}$ In preparing their response to McCarthy's recommendations, the senior officers

73. GMP, Jenkins objected to OC nominee (presumably Morton) as the subject of disciplinary enquiry, though later conceding this was inaccurate; Groves to Jenkins, 20 August 1975, Jenkins to Groves, 20 August 1975; circular letter NEC Sub-Committee, I 4 August 1975; agreed note of meeting between OC and General Secretary, is August 1975. Memo Jenkins to Groves, I 9 August 1975, Groves to Jenkins 20 August 1975: "your comment [...] that you did not like people who negotiated dishonestly was no doubt intended to impugn the integrity of the Officers' Committee". Memos of Groves to Jenkins, 28-29 August 1975; GPFC Minutes, I2 September I975; NEC Minutes, I 3 September 1975 ; circular Groves to OG, "Deductions from Salaries”, I 5 September 1975 .

74. GMP, McCarthy's preliminary adjudication of I 8 August 1975 had decided that Cotter receive ex-gratia payments in lieu of salary until the enquiry reported; memo Groves to Jenkins, 20 August 1975.

75. GMP, “Three Person Court on Judy Cotter: Resumé of First Day”, io August 1975. This copy, initialled JBF/PW, was apparently used by the OC.

76. GMP, OC notes, “Three Person Court on Judy Cotter: Officers' Committee Objectives and likely NEC. responses".

77. GMP, "Chairman's Report to the Parties by Dr W.E.J. McCarthy", pp. 5-6, § I 2, I 4 - I $5, \S_{33}$. McCarthy claimed limited competence in the law of employment contracts.

78. GMP, “Three Person Committee of Arbitration”, pp. I6-18, \$\$39-42.

79. NEC Minutes, I I October 1975; GMP, Memos Groves to OG, I3 October 1975; OC Minutes, I6 October 1975. The OC restated its belief in Cotter's integrity and the justice of industrial action.

80. NEC Minutes, 9 November 1975, where disciplinary action against Groves was considered; GMP, Memo Groves to OG, 20 November 1975; "Rough notes of [Essex] D[ivisional] C[ouncil] Meeting on officers dispute", i I October 1975. 
differed in the policies recommended. McCusker favoured simply a checklist for the assessment of trainees, with monitoring by divisional and national officers. Supporting Jenkins's scheme of an annual review of all officers, McCusker stressed that the ranks of the union offered the most promising pool for the appointment of fresh talent. ${ }^{81}$ Stan Davison had taken advantage of holiday leave to avoid the most bitter period of the dispute and diplomatically argued for a continuation of the status quo, balancing the intake of seasoned unionists with younger applicants. Muriel Turner's experience of the strike, and continuing battles with ultra-leftists and with disciplined communists such as Groves, led her to reach more ascorbic conclusions on the selection and training of officers. Turner argued that the seeds of conflict could be found in the frustrated ambition of well-educated and qualified officers who sought rapid promotion, noting that some fieldworkers believed that "the ability to articulate a certain set of political responses entitles them to a meal ticket in the tradeunion movement". She agreed with Jenkins's proposal to use the new training college at Bishop Stortford for officer induction, but emphasized the need for practical apprenticeship under an experienced officer. ${ }^{82}$

When presenting his recommendations to the NEC in November 1975, Jenkins skilfully added a suggestion that the union seek greater recruitment of black as well as female candidates, while the lay leadership reaffirmed the view that a proven record of union service was the most desirable and reliable quality sought in applicants for employment as officers. ${ }^{83}$ As battles over wage claims and the status of trainees continued with the OC during the winter of $1975-1976$, the Executive finally decided that future negotiations with field staff be conducted by a National Joint Council (NJC) similar to that which existed for clerical grades. ${ }^{8}$ As the OC demanded a programme of staff training, with regular reports and a grievance procedure for probationary staff, agreement was reached when the OC conceded to the NEC the right to make the final decision in any dispute involving trainees, and the NEC accepted the OC's proposals for training and supervision. Both parties then joined a working party to establish the new NJC. ${ }^{85}$

The legacy of the officers' dispute remained uncertain and unclear even

8г. ASTMS, 79/AS/3/8/80, Jenkins to McCusker, "Memo on Selection, Training and Monitoring of Fulltime Staff", I6 October 1975; Jenkins to McCusker, I3 November 1975, McCusker to Jenkins, I I November and i9 November 1975.

82. 79/AS/3/8/80, Davison to Jenkins, 21 October 1975, Turner to Jenkins, (n.d. c.22 October 1975).

83. NEC Minutes, 9 November 1975 .

84. GPFC Minutes, Io October-7 November 1975, I 2 December I975, I 5 January I976, I 3 -I 4 February-I 2 March 1976; communications from Don Groves, 3 July 2002, and Greta Karpin, 8 July 2002; GMP, Morton's notes of meeting of OC, 7 December 1975.

85. NEC Minutes, I4 February 1976. 
to many of the key actors. After insisting on his absolute prerogative to manage trainees as the agent of the NEC, Jenkins was forced to concede that the absence of formal, written reports left him vulnerable to the charge that he had acted on incomplete or inaccurate information. ${ }^{86}$ The authority of Jenkins and the NEC was only sustained at the cost of considerable division on the NEC as well as among the officers. ${ }^{87}$ While the field officers were clearly divided by late 1975 , their committee remained determined to restrict Jenkins's capacity to exercise his prerogatives over trainees in future. ${ }^{88}$ Although Jenkins and Turner expressed bitter hostility to the ultra-left, the Trotskyites had little influence over the origins or progress of the dispute. The Officers' Committee of the union had been dominated by communist and labour activists since the formation of ASTMS. In common with many of his officers, Jenkins shared a warm relationship with Bert Ramelson and the Industrial Department of the Communist Party. It was the Party's efforts to intercede in the dispute and to bring about the end of the strike which led to considerable anger and recrimination when the industrial action collapsed. A later meeting between Ramelson and the disaffected ASTMS officers in summer 1976 did little to repair relations, many officers abandoning the Party or aligning with the resistance to its leadership as it steered towards the "Eurocommunist" reforms. ${ }^{89}$

In the aftermath of the officers' strike, Jenkins and his allies turned their fire not on the communists but on their ultra-left critics, with a decisive legal victory for libel against the Trotskyite Socialist Worker. This prompted a fresh clash with the field officers, as Trotskyite officers, with the support of Groves and the OC, circulated a petition calling on the NEC to forgo the crippling damages awarded against the newspaper. When the signatories duly appeared in the offensive journal, controversy

86. GMP, "Contract of Service: Trainee Officers", n.d. NEC Minutes, 9 August 1975. The contract provided for two periods of six months probation, followed by appointment as Industrial Officer for a maximum of a year, after which officers were allocated to a division and represented by the OC. The Officer Coverage Committee discussed with the OC new draft procedures prior to the dispute, without changes to the training provisions. Groves interview, I 3 March 2002.

87. GMP, Groves to Jenkins, 23 July 1975. The threat of disciplinary action against Morton was withdrawn. He resigned his position later in 1976. Gary Morton interview, 22 April 2002. Comerford was appointed a national officer in 1978; NEC Minutes, 9 December 1978.

88. GMP, Morton ms notes of OG meeting, 7 December 1975. Morton summarized the role of key personalities: "T.[erry] C[omerford] and C.[live] J.[enkins] the butchers - with R. McCusker with a walk on part as butcher's boy". Morton's call for a reassertion of the right by the OC to represent all officers was passed 24 to 22 .

89. GMP, Morton ms notes of Communist Party meeting, dated (incorrectly?) I August I976, refer to four and "in partic[ular] 2 renegades"; Morton interview, 22 April 2002. Groves interview, I3 March 2002, indicates that the efforts of the Party to end the strike "became available" to, as distinct from being sought by, Jenkins. 
exploded as Jenkins pursued a small core of ringleaders and persuaded the NEC to demand that their Coventry official, John Fisher, offer his resignation. ${ }^{\circ}$ The officer was only saved by a surge of support in the Midlands and a threat of public demonstrations, forcing a reluctant Executive to agree that the Trotskyite official be given his (second) "final warning". ${ }^{91}$ Attempts to discipline Ian Gibson for his part in the affair similarly failed, and the union's internal Appeal Court also permitted him to stand once again for election to the NEC in late $1977.9^{2}$ It was in this period of intense political debate after the settlement of the 1975 dispute that the ASTMS's field officers pressed for greater freedom in the development of their careers as well as discussing NEC reforms in the management of their workloads. Jenkins's inclination to discipline ambitious officers who disregarded union rules was moderated by his NEC, with the right of officers to appeal to the NEC before dismissal being confirmed, and it was also agreed that officers should be permitted to stand for election to public office providing their individual applications were approved by the NEC. 93

The new National Joint Council (NJC) began work in summer I977, though the status of the Disciplinary Committee remained in dispute. The NEC insisted that it should be confined to members of its key committee. ${ }^{94}$ Jenkins finally conceded that the officers' representatives on the NJC could discuss the salaries and conditions of probationers, while preserving his discretion in deciding their tenure during the first six months of employment. Within a year the NEC decided that a comprehensive review of union finances and administration was required. Attempts to frame a code of practice for their field staff, including rules for trainees, were repeatedly stalled by protests from the OC and matters were referred to the NJC. ${ }^{95}$ Jenkins and his Executive were convinced that tighter management of officers was needed, with national officials appointed as the "middle management" within the union. In response to OC claims that the bargaining officers should remain autonomous, the leadership agreed that "over-the-should type of supervision" was not

90. NEC Minutes I2 February 1977, I6-17 April 1977, I4 May 1977. Twenty-seven officers signed the Groves-Fisher petition at the Birmingham meeting of the OG while the Divisional Council for the Midlands and even the NEC member for the area (Stan Jefferson) also called for the damages to be waived. Interview with John Fisher, 6 August 2002.

91. NEC Minutes 9 July 1977; Fisher interview, 6 August 2002.

92. NEC Minutes, 9 July 1977, 8 October-I 2 November I977, I4 January I978. Gibson was not elected.

93. NEC Minutes, 9 October 1976, I I-I 2 December 1976, I 2 February 1977.

94. NEC Minutes, I2 June 1976, i I June 1977. The Disciplinary Committee was drawn from General Purposes and Finance Committee.

95. NEC Minutes, I4 October 1978, II-I2 November 1978, Io February 1979, 7-8 April I979. 
necessary but insisted that national appointees should brief the divisional officers in the field. ${ }^{6}$

These debates about the management of officers contributed to a larger discussion on the shape and direction of the union as it had evolved in the decade since ASTMS's formation. An important feature of the rapid expansion from little more than 50,000 to 400,000 members had been the emergence of National Advisory Councils (NAC). At the end of 1977 almost 100 NACs were in place, half of them chaired by members of the NEC and serviced by field officers, and increasingly supported by employees seconded from large firms as lay representatives. ${ }^{97}$ The spread of advisory councils across industries and larger firms was undoubtedly an attempt by the union to extend the reach of its bargaining and counter the opposition of many employers to industry-wide agreements, particularly where the grip of the traditional employer associations was being relaxed as more companies bargained directly with unions. It also reflected the diverse ethnicity of the employees now organized by ASTMS and the sectional divisions within the structure of the organization as merged unions and staff associations preserved some identity within the larger union. The representatives of the field officers argued that this specialization of membership services within the union and the increased bargaining with larger, multi-plant firms had increased the burden on Divisional Officers and also pointed to the need for management of field officers on an industrial rather than regional basis. $9^{8}$ The OC challenged what they claimed was Jenkins's tendency to appoint individual officers to specialist roles, often enhancing their visibility and easing their promotion within the union, rather than filling such positions by competitive interview among all officers. The NEC supported Jenkins in arguing that the handful of officers who were allocated to such tasks were asked to spearhead particular campaigns and returned to their former duties in most cases. ${ }^{99}$

By 1979 an accommodation had been reached where National Officers assumed a briefing role in the field but their subordinates continued as autonomous agents in their working lives as bargainers. After years of exclusion from the inner councils of the British TUC, Jenkins was steadily ascending the ladder of political influence within the labour movement in

96. 79/AS/I/27/I, National Joint Council for Full-time Officers, Minutes [hereafter NJC Minutes], 24 June 1977, I7 November 1977 Appendices. The wages and conditions of all officers apart from the General Secretary and probationers were bargained by the NJC.

97. NEC Minutes, II June 1977, I2 November-10 December 1977. Seven industry-wide advisory councils were given NEC members as chairmen, in addition to many single-firm councils.

98. NJC Minutes, 20 February 1979, Appendix I, OC Paper.

99. NJC Minutes, I7 November 1977, 27 July 1978, Appendix. Forty-one full-time seconded representatives to NACs were identified. Among seventy-five divisional officers and seven industrial officers only a handful of specialists were identified. 
the late I970s. The leadership of the union continued to be aligned with left-wing policies of state investment and regulation, though in a decisive debate on the proposed nationalization of the insurance and finance industry ASTMS voted clearly to resist such radical initiatives as conference heard the concerns of its members faced with the prospect of redundancies if efficient rationalization was achieved in a publicly-owned industry. ${ }^{100}$ Jenkins remained a prominent critic of the wage policies designed by the Wilson and Callaghan governments in the dying years of the Social Contract and he argued for a return to free collective bargaining at the TUC in Autumn 1978, though the experience of industrial strife and a steep decline in Labour popularity during the following winter persuaded Jenkins to support a renewed concordat with the government in early $1979 .{ }^{\text {IOI }}$ By the end of the decade he had become widely identified with the moderate leadership of the Labour Party, and was said to spend more time at Congress House than managing his union. ${ }^{102}$

\section{CONCLUSIONS}

This article has been concerned with the leadership of a white-collar union and its impact on the working lives of trade-union officers. Much of the earlier discussion of union officials was defined by debates on the growth of collective bargaining among salaried staff, and the impact of broad changes on the capitalist economy and in class identities versus specific institutional and political initiatives associated with particular periods. Institutional studies of trade-union governance and radical accounts of trade-union bureaucracy have been followed by detailed empirical research (such as that by Undy and McCarthy) which stress the importance of centralization, concentration, and occupational density in the progress of unionism. The initiatives by dynamic leaders such as Jenkins in promoting growth by pursuing general unionism via aggressive mergers are seen as significant factors in the expansion of unions after 1968. While radical assessments of industrial conflict identified workplace struggle as the most vivid expression of capitalist conflict and class politics, Undy et al. share with most institutionalist studies an analysis of political life as largely external to the bargaining process. Although unions respond to political regulation and are periodically beset by factionalism, their purpose and outlook is shaped by their primary function as industrial bargainers.

There could be no better example of a successful recruiter or bargainer in the history of white-collar unionism than Clive Jenkins. His genius as a

100. NEC Minutes, i I September 1976, I 2 February-9 July 1977, i I February 1978.

IоI. NEC Minutes, 9 September-9 December 1978, I० February-ı० March 1979.

102. Keith Harper in The Guardian, 7 June 1980, for example; from cuttings in BBC Archives at Caversham. 
union leader was to recognize, by the early i960s, both the huge potential for growth among salaried staff and the historical failure of unions such as ASSET to attract such members. Breaking with earlier practices of genteel understandings and appeals to partnership with the employers, the Jenkins years were marked by a fierce insistence on the fundamental importance of effective bargaining as the test of union achievement and the foundation for sustained recruitment. Jenkins's predecessors in ASSET had learned that the model of organization and job regulation which the manual unions developed could not be easily applied to the dispersed employment and diverse career patterns of the salaried grades, even if employers and bluecollar groups had been less hostile. While drawing on the techniques and discipline of bargaining which the officers and members learned in the metalworking trades which still dominated ASSET membership in 1968, the union had also recruited in a range of technical and administrative grades by emphasizing its appeal to nonmanual staff who enjoyed differential advantages over the shopfloor. The inspiration for the quasilegal approach to employment contracts, which contrasted markedly with the aversion of most unions to any legislative or legal regulation, can also be traced to the hard experience of the postwar years and continued to inform the practical culture of the union and its bargainers after the formation of ASTMS.

In assembling a repertoire of bargaining techniques through a process of learning by doing, Jenkins and his contemporaries developed a way of thinking about industrial relations which was retained beneath the rhetoric of modernization and slick advertising campaigns that offered organization to the "middle classes". As Assistant General Secretaries, McCusker, Davison, and Turner embodied the distinctive bargaining approaches of ASTMS as well as the union's range of industrial experience after 1968. For the collective knowledge acquired by the Association was framed within the core values of British trade unionism expressed by its consistent membership of the TUC since the I920s. In arguing for the collective organization of managers and supervisors as well as technical experts, ASSET had followed Mikardo's lead in coupling the case for scientific management to ideas of socialist efficiency and the planned economy. Jenkins similarly linked his appeal to salaried workers and the defence of differentials with radical attacks on wage controls and legal challenges to Labour as well as Conservative ministers. To the public vocabulary of modernization, free bargaining, and private affluence bargaining Jenkins added a political subtext of public investment and legal reform which preserved his socialist credentials but left him exposed in the debates on labour legislation after 1970 .

The spectacular rise in ASTMS membership after 1968 registered the ability of its leaders to exploit these different strands in a period of general expansion for white-collar unions. The bargaining methods and intellec- 
tual expertise which had been acquired in the ASSET days were retained, even as the union abandoned any pretence at concentrating its activities within specific occupations and ventured into the virgin territory of financial services when the most slender of opportunities appeared. The triumph of strategy over structure which marked the Jenkins years also created serious strains in an organization which was slow to develop bureaucratic methods to administer its membership or manage staff relations. By the late I960s the tempo and the scope of bargaining changed when salaried staff engaged in industrial actions which were rare if not unknown before 1965. The scientific workers brought with them a handful of precious national agreements, such as that with the National Health Service, but most bargaining continued to be conducted with individual firms or even the plants of larger companies. In some instances this led to the incidents of "guerrilla warfare" recorded in the West Midlands, while Muriel Turner and her colleagues in financial services devised conciliatory methods for dealing with the insurance and banking institutions where they tailored procedural agreements to individual companies. These variations in bargaining philosophy and method can be traced to the distinctive culture of the union as well as the concern of key officers to nurture a close relationship with different sections of members. Radical officials were particularly influential in the Midlands manufacturing districts while London and the southeast remained a stronghold of both communist and moderate influence as financial services became a substantial constituency.

It has been argued by some commentators that Jenkins enjoyed the benefits of centralization in policy-making while his leadership developed a diffuse, variegated system of representation for the distinctive interest groups of ASTMS. The evidence surveyed here casts some doubt on Jenkins's dominance of the NEC as well as his tight control of administration. His capacity to govern appears to have been more conditional than is often acknowledged. Relations between ASTMS officers in these years of growth bore the imprint of political as well as physical strains which expansion imposed on the union. Growth in members and income enabled the union to recruit officers in substantial numbers for the first time, including those with limited industrial experience who possessed the education and character to appeal to the salaried nonunionist, and to develop skills in media communication as well as specialist bargaining. The training programme remained perfunctory but the Association offered the prospect of a well-paid career to younger, qualified candidates who were invited to share the professional ambitions of the occupations they recruited. It was also expected that the political sympathies of the officers would remain clearly aligned with the aims of British trade unionism, as the union exploited the resurgence in left-wing politics after 1968 to recruit large numbers of younger, intellectual officers. 
There were early signs of strain with the AScW officers as John Dutton was dispatched with little ceremony, irritating his colleagues on the NEC, while the training programme was criticized by seasoned AScW members who became OC negotiators. Despite his undoubted prestige, Jenkins also found his preferences for promotion and demotion were frequently thwarted by his NEC. Attempts to dismiss troublesome officers led to crisis and failure in the I970s. Relying on personal charisma and patronage in dealing with the officers as well as lay leaders, Jenkins was slow to develop systematic methods of training, supervision and promotion for the field officers. Differences between field officers and the leadership were amplified after the introduction of trade union reforms by the Heath government, leading to divisions on the NEC and its decisive defeats at the hands of conference in I $97 \mathrm{I}-\mathrm{I} 972$ as many field officers orchestrated the opposition to registration. The controversies which arose at this period were undoubtedly informed by the radical political views of many officers, though it is difficult to argue that factionalism on the NEC or among the officers was itself a serious threat to Jenkins's policies and position. He continued to share with most of his officials the Tribunite and communist outlook which characterized the leadership of the union throughout these years.

The Cotter affair, and the acrimonious dispute which followed her dismissal, was not the result of factional opposition to Jenkins or political divisions in the ranks of the officers. The strike bitterly divided the large communist grouping among the fieldworkers and even some of Jenkins's admirers in the Officers' Group. The strike arose after a complex series of earlier struggles which convinced Jenkins and the NEC that they should assert their right to manage their restive workforce. The dispute and the subsequent battles with Trotskyite officers in the Socialist Worker case demonstrated the considerable difficulty the NEC faced in its efforts to discipline autonomous bargainers who used their constituency support to defend their working conditions and privileges. In contrast to the model outlined by Undy et al., it can be argued that in practice the decentralized system of bargaining and representation by divisional councils and advisory committees affected the capacity of the NEC to implement policies as well as control its workers. Jenkins recognized the point in seeking to cultivate personal support and NEC representation among the large groups of finance workers at this period. For the price the leadership faced in crushing the 1975 strike was that the prestige of its General Secretary was never again to reach the heights he enjoyed in the golden age of expansion and recruitment after 1968 . His influence continued to grow at the TUC and in the Labour Party as well as in the lucrative world of the British mass media, but the praise showered on Jenkins in early 1975 by his mentor Ian Mikardo was to prove seriously premature. 